\title{
The Relationship Of Knowledge And Attitudes Of Young Women With Personal Hygiene Behavior When Menstruating
}

\author{
Linda Kusumawati ${ }^{1}$, Adriana Palimbo ${ }^{2}$, Febrianti Sari ${ }^{3}$ \\ $\left\{\right.$ lindakusumawati@unism.ac.id ${ }^{1}$, adrianapalimbo@unism.ac.id $\left.{ }^{2},\right\}$ \\ Universitas Sari Mulia, Banjarmasin ${ }^{1,2,3}$ \\ *lindakusumawati@unism.ac.id
}

\begin{abstract}
Personal Hygiene is an action to maintain the cleanliness and health of a person in maintaining good physical and psychological health. The lack of knowledge of adolescent girls about Personal Hygiene during menstruation will have an impact on the attitudes of young women in behaving to maintain their reproductive health. Objective: The purpose of this study was to analyze the relationship between attitudes and knowledge of adolescent girls with personal hygiene behaviors. Method: The research design used in this study was correlation using a cross sectional approach with a total sample of 51 people. Results: The results showed that knowledge in the good category was $39.2 \%$, attitudes in the good category were $56.9 \%$ and behavior in the good category was $56.9 \%$. Simpullan is a relationship between attitude and knowledge with personal hygiene behavior during menstruation.
\end{abstract}

Keywords: Teenagers, Personal Hygiene, Behavior, Mentruation

\section{Introduction}

Attitude is a general evaluation made by humans towards themselves, others, objects or issues [1]. Knowledge is the result of "knowing" and this happens after people have sensed a certain object. [2] A teenager is someone who has an age range of 10-19 years. Teenagers are a period where a person's secondary sexual signs have developed and reach sexual maturity. Teenagers also experience physical, psychological, and social maturity. [3]

Personal Hygiene is a treatment where the individual maintains his health, influenced by values and skills. [4]. Behavior is an individual's response to a stimulus or action that can be observed and has a specific frequency, duration and purpose whether realized or not or can be said behavior is a collection of various factors that interact with each other, sometimes we do not have time to think about why someone is implementing certain behaviors. [5]

Menstruation is a situation of endomentrium release in the form of splinters and bleeding due to the release of the hormone estrogen and progesterone which drops and stops causing vasoconstriction of blood vessels which is immediately followed by vasodilation. [6]

The results of a preliminary study conducted at Alalak State High School by interviewing 6 people found that 4 people had less knowledge about personal hygiene when menstruating with the habit of only replacing pads when full, using tight pants, the reasons for 
not being translucent and does not absorb sweat, and uses feminine soap. Whereas 2 other people have good knowledge with the habit of changing pads 4 times or more, using pants that are not too tight and absorb sweat so as not to damp, and clean the female area from front to back and do not use female soap. This study is in line with research conducted by Wati (2006) in SMP Negeri 3 Gamping Sleman Yogyakarta showing that the level of knowledge of female students at the time of pre-test there were 30 respondents $(78.9 \%)$ who were highly knowledgeable and 8 respondents $(21.1 \%)$ moderate knowledge of hygiene during menstruation and an increase in the post-test there were 30 respondents $(97.4 \%$ ) highly knowledgeable about hygiene during menstruation and only 1 respondent $(2.4 \%)$ had moderate knowledge about hygiene during menstruation.

Young women have a low level of knowledge and understanding of Personal Hygiene behavior. This is due to lack of information received because in Indonesia, reproductive health education has not been done much. Reproductive health education is not included in the school curriculum as recommended by WHO, because there is a conflict between the values of Indonesian tradition and Westernized globalization that is considered to emerge as a result of reproductive health education. [7]

From a preliminary study that has been done at Alalak State High School, it is a secondary school that has never received health education counseling about personal hygiene during menstruation. From this the researchers are interested in conducting research at the high school given that health workers have not been touched by reproductive health.

This study aims to find out the relationship between attitudes and knowledge of young women towards personal hygiene behavior when menstruating at Alalak State High School.

\section{Methods And Procedures}

This research method is a correlation research method using a cross sectional approach. Data were collected by distributing questionnaires directly to students at Alalak State High School. Based on the functional relationship between variables or with others, the variables can be divided into two namely the dependent variable or the dependent variable and the independent variable or the independent variable [8].

The dependent variable of this study was the personal hygiene behavior of young women in Alalak State High School when menstruating and the dependent variable was Knowledge and Attitude. the population in this study was 106 young people at Alalak State High School. In this study the sample was taken by random sampling technique so that the sample amounted to 51 people.

Data collection was carried out using a questionnaire that was distributed directly to class $\mathrm{X}$ students at Alalak State High School.

\section{Results}

The number of students at Alalak State High School is 714 students. In this study, the sample of the study was 51st grade students of Alalak State High School, totaling 51 female 
students. Following are the results of the analysis of data on knowledge of Young Women in Alalak State High School.

Table. 1. Frequency Distribution of Adolescent Girls' Knowledge at Alalak State High School.

\begin{tabular}{lllc}
\hline No & \multicolumn{1}{c}{ category } & Frequency & $\%$ \\
\hline 1. & Good & 20 & 39.2 \\
\hline 2. & Enough & 19 & 37.3 \\
\hline 3. & Not good & 12 & 23.5 \\
\hline & Total & 51 & 100 \\
\hline
\end{tabular}

Following are the results of the analysis of data on Young Women Attitudes at Alalak State High School.

Table. 2. Frequency Distribution of Young Women Behavior in Alalak State High School

\begin{tabular}{clll}
\hline No & \multicolumn{1}{c}{ category } & $\begin{array}{l}\text { Frequen } \\
\text { cy }\end{array}$ & $\%$ \\
\hline 1. & Good & 29 & 56.9 \\
\hline 2. & Not good & 22 & 43.1 \\
\hline & Total & 51 & 100 \\
\hline
\end{tabular}

Based on the cross tabulation with the sperman rank test on the relationship of Knowledge with self-propulsive behavior during menstruation is as follows:

\begin{tabular}{|c|c|c|c|c|c|c|}
\hline \multirow[t]{2}{*}{ No } & \multirow[t]{2}{*}{ knowledge } & \multicolumn{4}{|c|}{ behavior } & \multirow[t]{2}{*}{ Total } \\
\hline & & Good & $\%$ & Not good & $\%$ & \\
\hline 1 & Good & 16 & 80.0 & 4 & 20.0 & $20(100 \%)$ \\
\hline 2 & Enough & 11 & 57.9 & 8 & 42.1 & $19(100 \%)$ \\
\hline \multirow[t]{2}{*}{3} & Not good & 2 & 16.7 & 10 & 83.3 & $12(100 \%)$ \\
\hline & & 29 & 56.6 & 22 & 43.1 & $51(100 \%)$ \\
\hline
\end{tabular}

Uji Spearman rank p. $0.023=<0.05$

Based on the table above, it is known that good knowledge of young women with good behavior is 16 people (80.0), while good knowledge of young women with bad behavior is 4 people (20.0). Adequate knowledge of young women with good behavior totaling 11 people (57.9), while adequate knowledge of young women with 
unfavorable behavior of 8 people (42.1). Knowledge of adolescent girls who are not good with good behavior are 2 people (16.7), while knowledge that is not good with bad behavior is 10 people (83.3).

Based on the results of bivariate analysis using the Spearman rank test obtained $\mathrm{p}$ value $=0.023$ because $\mathrm{p}<0.05(0.023<0.05)$, it can be stated the relationship between adolescent girls' knowledge and personal hygiene behavior during menstruation. Correlation coefficient ( $\mathrm{r}$ ) in this study was found to be 0.317 , this power was in the range of $0.26-0.50$ according to Colton, this strength was moderate.

Based on the cross tabulation with the sperman rank test on the relationship between Attitude and Self-Behavior when menstruating is as follows:

\begin{tabular}{ccccccc}
\hline No & Attitude & \multicolumn{4}{c}{ Behavior } & \multicolumn{2}{c}{ Amount } \\
\cline { 2 - 7 } & Good & $\%$ & $\begin{array}{l}\text { Not } \\
\text { good }\end{array}$ & \multicolumn{2}{c}{ \% } \\
\hline Good & 26 & 89.7 & 3 & 10.3 & $29(100 \%)$ \\
\hline Enough & 3 & 13.6 & 19 & 86.4 & $22(100 \%)$ \\
\hline Amount & 29 & 56.9 & 2 & 43.1 & $51(100 \%)$ \\
\hline
\end{tabular}

Uji Spearman rank p. $0.023=<0.05$

Based on the table above, it is known that the attitudes of good young women with good behavior are 26 people (89.7), while the good attitudes of young women with bad behavior are 3 people (10.3). The attitudes of adolescent girls who are not good with good behavior are 3 people (13.6), while the attitudes that are not good with bad behavior are 19 people (86.4).

Based on the results of bivariate analysis using the Spearman rank test, the value of $p=0,000$ was obtained because $p<0.05(0.000<0.05)$, so it can be stated that there is a relationship between the attitudes of young women with personal hygiene behavior during menstruation. Correlation coefficient (r) in this study was obtained for 0.555 , this power is in the range $0.51-0.75$ according to Colton, this strength is strong.

\section{Discussion}

Based on the results of research on adolescent girls' knowledge about Personal Hygiene during menstruation at Alalak State High School, most of the young women who have good knowledge are 20 people (39.2\%), 19 people have enough knowledge (37.3\%), and 12 people are poor $(23.5 \%)$. In this study, most teenage girls only change pads less than 4 times a day, they should change their pads during menstruation 4 times or more a day so that bacteria in the blood do not reenter the vagina. If during menstruation changing pads less than 4 times will cause infections such as abnormal vaginal discharge, odor and cancer. 
Knowledge of adolescent girls is not only limited to knowing how to replace pads several times a day but also how to clean genetal organs during menstruation. Based on experience and research it turns out that behavior based on knowledge will be better than behavior that is not based on knowledge.

The results of the study of personal hygiene knowledge with personal hygiene behaviors of girls during menstruation are the results of the study showed that most respondents had good knowledge about personal hygiene during menstruation as many as 41 respondents $(68.3 \%)$ because respondents had received information from parents and relatives who had have menstruation besides that they also get information from reading books and magazines [9].

Based on the results of research on Young Women Attitudes About Personal Hygiene During Menstruation at Alalak State High School, it was found that most of the young girls who had good attitudes were 29 people $(56.9 \%)$ and 22 people were poor $(43.1 \%)$.

This study is in line with research conducted by Maya [11] attitudes of young women 100 people $(75.2 \%)$ have good attitude, 31 people $(23.3 \%)$ have enough attitude and 2 people $(1.5 \%)$ have less attitude.

The act of maintaining hygiene during menstruation greatly affects the cleanliness of her reproductive organs, if a young woman knows many things about the actions that must be taken to maintain the health of her reproductive organs during menstruation the teenager should proceed to his actions / behavior so as not to cause an undesirable impact on the health of the reproductive organs. Factors that influence attitudes are: personal experience, the influence of others who are considered important, the influence of culture, mass media, educational and religious institutions, and emotional factors [12].

Based on the results of the study, it was found out that Adolescent Girls' Behavior About Personal Hygiene During Menstruation at Alalak State High School showed that most of the young girls who had good behavior were 29 people $(56.9 \%)$ and less good categories were 22 people $(43.1 \%)$.

This study is in line with research conducted by Dewi [13] The results showed that most respondents had good behavior during menstruation as many as 32 respondents $(53.3 \%)$, quite as many as 27 respondents $(45.0 \%)$, less as much as 1 respondent (1.7\%).

At the moment everyone's behavior depends on the individual himself, how he responds to it. Cleanliness during menstruation greatly affects the impact that will be experienced if the individual does not care about the things that need to be considered by young women during menstruation, namely: skin and face care, hair hygiene and body hygiene by taking a bath twice a day, cleaning the female area with wash it off using clean water and when cleaning the female area no need to use cleaning fluid [13].

The results of the study of the relationship of adolescent girls' knowledge with personal hygiene behavior during menstruation showed the results that most of the knowledge of good young women with good behavior were 16 people (80.0), while good knowledge of young women with bad behavior was 4 people (20.0). Adequate knowledge of young women with good behavior totaling 11 people (57.9), while adequate knowledge of young women with unfavorable behavior of 8 people (42.1). Knowledge of adolescent girls who are not good 
with good behavior are 2 people (16.7), while knowledge that is not good with bad behavior is 10 people (83.3).

Based on the results of bivariate analysis using the Spearman rank test obtained $\mathrm{p}$ value $=0.023$ because $\mathrm{p}<0.05(0.023<0.05)$, it can be stated the relationship between the knowledge of adolescent girls with personal hygiene behavior during menstruation. Correlation coefficient ( $r$ ) in this study was found to be 0.317 , this power was in the range of 0.26-0.50 according to Colton, this strength was moderate.

This study is more dominant in the category of good knowledge with good behavior 16 people $(80.0 \%)$ due to the knowledge of young women about menstruation understanding and applying it a lot with direct behavior or actions not just knowing but not doing their actions and bad knowledge with bad behavior caused young women have less knowledge about how many times to change pads during menstruation will affect the behavior of changing pads less than 4 times a day.

The results of the study of the relationship of adolescent girls' attitudes with personal hygiene behaviors is known that good attitudes of young women with good behavior are 26 people (89.7), while good attitudes of young women with less good behavior are 3 people (10.3). The attitudes of adolescent girls who are not good with good behavior are 3 people (13.6), while the attitudes that are not good with bad behavior are 19 people (86.4).

In this study most of the young women have good attitudes and apply them through good behavior, young women begin to understand how to maintain hygiene during menstruation seen from their knowledge, attitudes and behavior.

The category of good teenage girl attitudes with good behavior 26 people $(89.7 \%)$ is caused because young women have an attitude that understands the importance of hygiene during menstruation such as before and after cleaning the female organs should wash hands and apply them through actions during menstruation washing hands before and after cleaning reproductive organs. The categories of adolescent girls' attitudes are not good with bad behavior 19 people $(86.4 \%)$ due to young women do not understand how many times to change pads when menstruating

\section{Conclusion}

From the results of research conducted at Alalak State High School with 51 female adolescent respondents obtained analysis that the knowledge of young women about personal hygiene during menstruation at Alalak State High School is mostly in the good category of 20 people $(39.2 \%)$, attitudes of young women about personal hygiene during menstruation at Alalak State High School is mostly in the good category that is 29 people (56.9\%), adolescent girls behavior about personal hygiene when menstruating at Alalak State High School is mostly in the good category that is 29 people $(56.9 \%)$, there is a relationship between adolescent knowledge daughter with personal hygiene behavior during menstruation. Correlation coefficient (r) obtained by 0.317 this strength is in the range $0.26-0.50$ according to Colton, this strength is moderate and there is a relationship between the attitudes of young 
women with personal hygiene behavior during menstruation. Correlation coefficient (r) obtained by 0.555 this strength is in the range $0.51-0.75$ according to Colton this strength is strong.

\section{References}

[1] Azwar, S. 2011. Sikap Manusia Teori dan Pengukurannya. Yogyakarta: Pustaka Pelajar.

[2] Notoatmodjo, Prof. Dr Soekidjo.2003. Pendidikan dan Perilaku Kesehatan. Jakarta: Rineka Cipta.

[3] World Health Organiza on (WHO). (2015), 'Adolescent Development: Topics at Glance'.

[4] Meiner Sue E. (2011). Gerontologic Nursing 4th ed. Elsevier: Mosby.

[5] Wawan dan Dewi, 2010. Teori dan Pengukuran Pengetahuan, Sikap, dan Perilaku Manusia. Yogyakarta: Pustaka Pelajar.

[6] Prawiharjo, Sarwono. 2014. Ilmu Kebidanan. Jakarta : Bina Pustaka.

[7] Benita, R. 2012. Pengaruh Penyuluhan terhadap Tingkat Pengetahuan Kesehatan Reproduksi pada Remaja Siswa SMP Kristen Gergaji. Jurnal Medica Muda, 1(1) : 1- 17

[8] Hidayat, A. Aziz Alimul. 2007. Metode Penelitian Keperawatan dan Teknik Analisa Data. Jakarta: Salemba Medika.

[9] Dewi, A. 2014. Hubungan Pengetahuan Tentang Personal Hygiene dengan Perilaku Personal Hygiene Remaja Saat Menstruasi di Sekolah Menengah Pertama Islam Terpadu Harapan Bunda Pedurungan. Semarang.

[10] Nurlita, Widya. (2014). Gambaran Tingkat Pengetahuan dan Perilaku Menjaga Kebersihan Organ Genetalia pada Siswi MI Pembangunan. Skripsi. Universitas Islam Negeri Syarif Hidayatullah Jakarta.

[11] Ayu, F dan Maya, K. 2010. Hubungan Antara Komunikasi Ibu-Anak dengan Kesiapan Menghadapi Menstruasi Pertama pada Siswi SMP Muhammadiyah Banda Aceh. Ejournal Undip.

[12] Azwar, S. 2011. Sikap Manusia Teori dan Pengukurannya. Yogyakarta: Pustaka Pelajar.

[13] Yuni, Natalia Erlina. "Buku Saku Personal Hygiene". Yogyakarta: Nuha Medika, 2015. 